\title{
Unpublished Magdalenian art from Pont d'Ambon (Bourdeilles, Dordogne, France)
}

Des cuvres d'art magdaléniennes inédites à Pont d'Ambon (Bourdeilles, Dordogne, France)

\section{Patrick Paillet, Elena Man-Estier and Peggy Bonnet-Jacquement}

\section{OpenEdition}

\section{Journals}

\section{Electronic version}

URL: http://journals.openedition.org/paleo/2866

DOI: $10.4000 /$ paleo.2866

ISSN: 2101-0420

\section{Publisher}

SAMRA

\section{Printed version}

Date of publication: 15 December 2013

Number of pages: $249-255$

ISSN: $1145-3370$

\section{Electronic reference}

Patrick Paillet, Elena Man-Estier and Peggy Bonnet-Jacquement, « Unpublished Magdalenian art from Pont d'Ambon (Bourdeilles, Dordogne, France) », PALEO [Online], 24 | 2013, Online since 15 September 2015, connection on 07 July 2020. URL : http://journals.openedition.org/paleo/2866 ; DOI : https:// doi.org/10.4000/paleo.2866

This text was automatically generated on 7 July 2020 .

\section{(c) (†)}

PALEO est mis à disposition selon les termes de la licence Creative Commons Attribution - Pas d'Utilisation Commerciale - Pas de Modification 4.0 International. 


\section{Unpublished Magdalenian art from Pont d'Ambon (Bourdeilles, Dordogne, France)}

Des ouvres d'art magdaléniennes inédites à Pont d'Ambon (Bourdeilles, Dordogne, France)

Patrick Paillet, Elena Man-Estier and Peggy Bonnet-Jacquement

\section{Introduction}

1 The Collective Research Project entitled "settlements and cultures at the end of the Tardiglacial in north Perigord", directed by P. Paillet, aims to characterize the cultural transition from the upper Magdalenian to the Azilian/Laborian between the Dronne and Tardoire Basins, within the Charente boundaries. This research focuses on several sites, such as the habitat sites of Rochereil, Pont d'Ambon, La Peyzie, or the painted caves of La Mairie (Teyjat) or Fronsac (Vieux-Mareuil).

2 As part of this research, we conducted fieldwork (test pits, excavations, surveys...) and undertook a systematic review of the early collections.

3 For the site of Pont d'Ambon, we studied the faunal remains issued from the G. Célérier excavations (1970 to 1987). These collections are curated at the National Prehistory Museum and are mostly from the Laborian (layer 2) and Azilian levels (layers 3 and 4) of the rock shelter. We identified numerous engraved bone fragments, some of which clearly recall the Laborian style (Paillet, Man-Estier, submitted and accepted). A detailed publication will be devoted to these pieces.

In 1987, G. Célérier conducted a test pit in the levels underlying "middle layer 4", or “"'median 4", attributed to the final upper Magdalenian (lower layers 4, 5 and 6). The exploration of these layers was made possible by the artificial lowering of the level of the Dronne. For practical reasons, the test pit was limited to a single square metre (square J8) (Célérier 1991). 
In spite of this limited extension (fig. 1), G. Célérier identified the presence of three thin successive human occupation levels from a "final stage of the upper Magdalenian" (Célérier 1991, p. 11 and Célérier 1998, p. 237). The levels are made up of expanses or beds of quartzite pebbles, often reddened by fire and shattered, coated in combustion residues and separated by sterile sandy layers (Célérier 1996). The lithic industry is abundant and contains many fine backed bladelets in beige flint and burins. Several micro-borers and Laugerie-Basse points, mainly in local Santonian flint, complete the range of lithic tools. These levels also contain an ample bone industry and G. Célérier notes that it is almost exclusively made on reindeer antler and that the rods were extracted using the parallel double groove technique. He also mentions several tools destined to work soft materials (awls, lissoirs, perforated needles), as well as some rare bilaterally barbed harpoons (fig. 2) and a pendant imitating a perforated red deer canine (Célérier 1996) (fig. 3). The abundant consumed fauna is mainly made up of reindeer remains. The presence of several fish, mainly Salmonids, is noteworthy. No objects of art have been mentioned in previous publications related to these levels.

The transition between the Magdalenian and the Azilian is located in the same sedimentary context. In contrast, G. Célérier points out the brutal passage between "lower layer 4" and "middle layer 4", where the red deer and the rabbit are exploited rather than the reindeer, where the bone industry disappears and where the lithic industry contains more end scrapers and less burins and backed bladelets.

Figure 1 - Map and grid from the site of Pont d'Ambon. Drawing E. Man-Estier after G. Célérier.

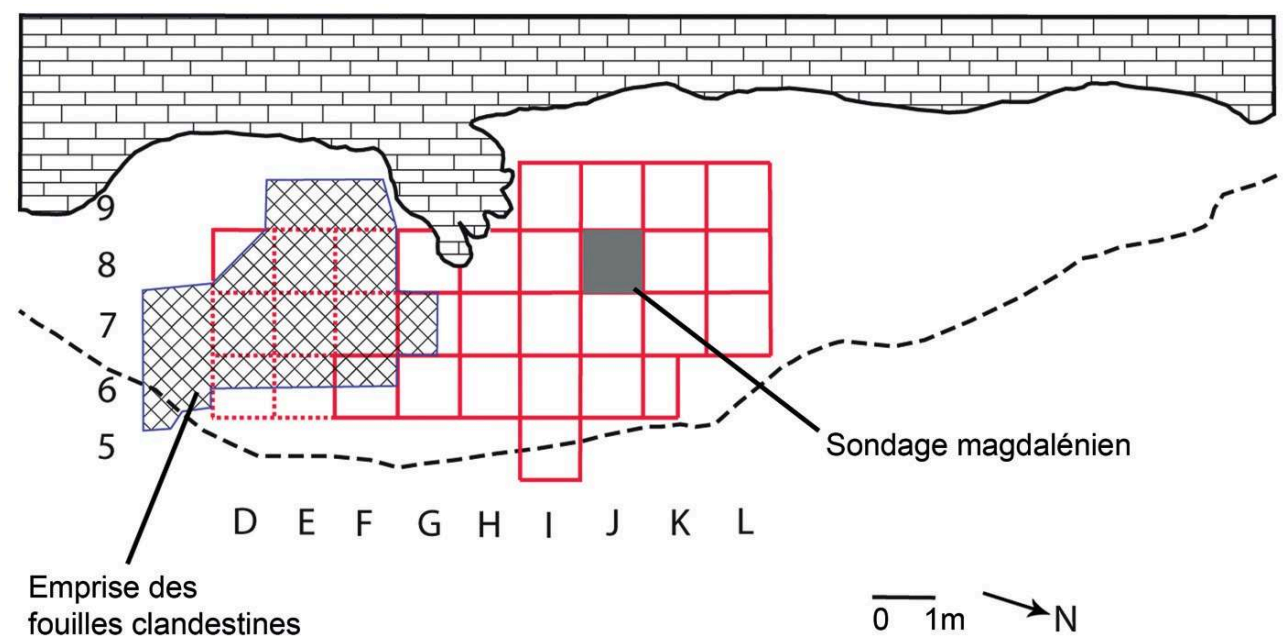


Figure 2 - Bilaterally-barbed decorated harpoon.

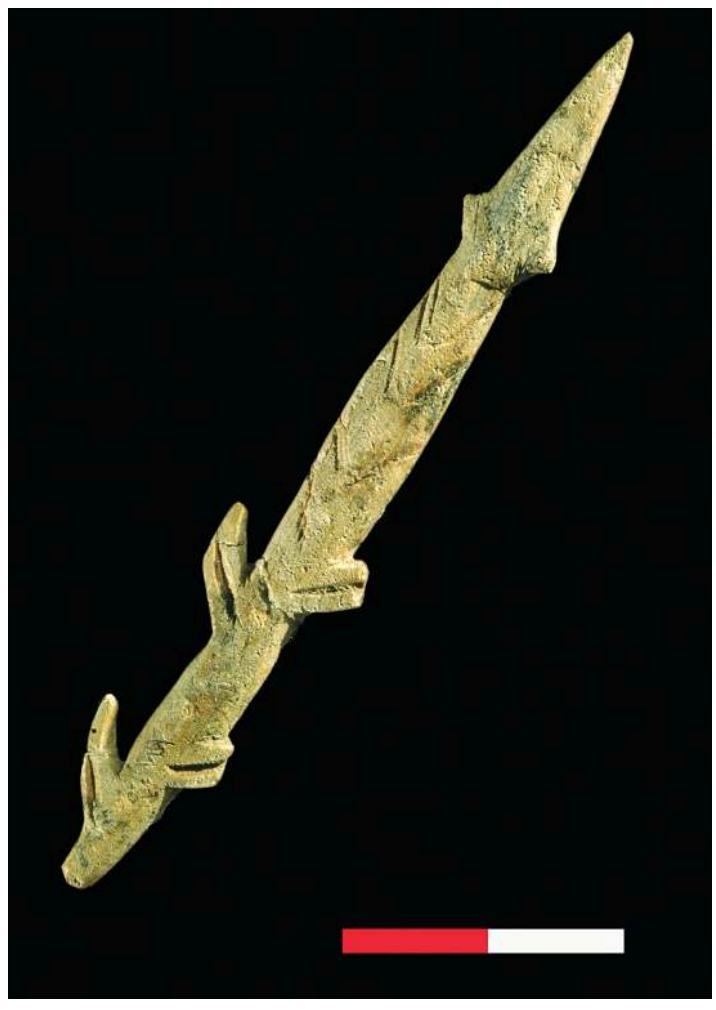

Figure 3 - Perforated and incised deer canine.

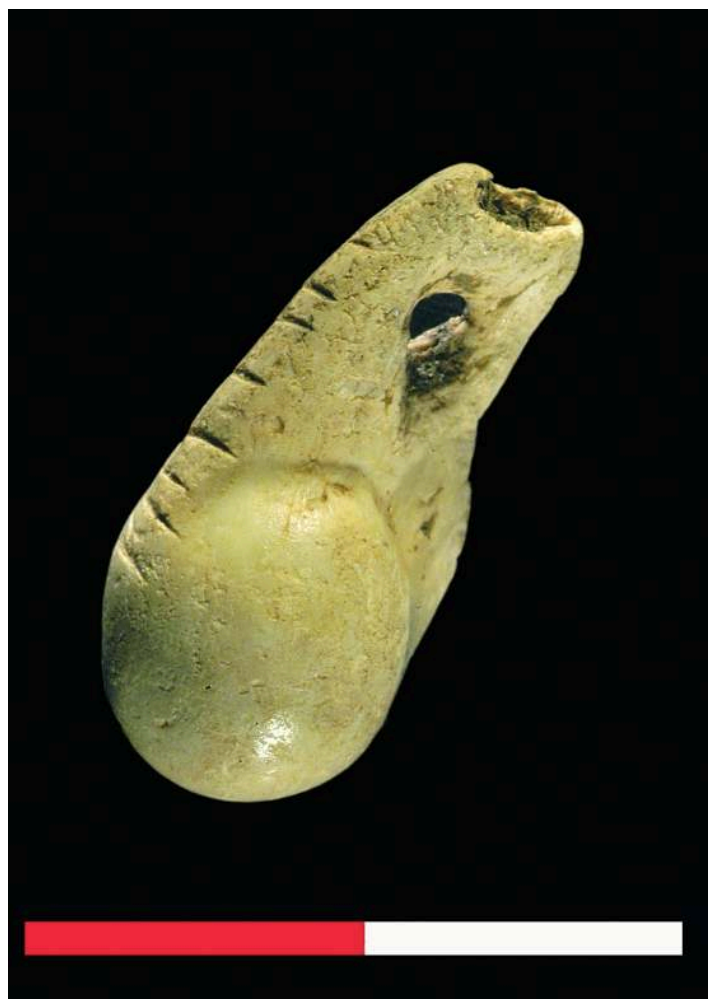




\section{Objects of art in the fauna}

7 The systematic review of the faunal series from the Magdalenian levels from square J5 led to the identification of several bone tool elements (perforated needles and lissoirs or polishers), as well as three fragments of engraved bone. These are all from layer 5 (square J8).

Piece $\mathrm{n}^{\circ} 1$ (Inventory number PCR - PDA61) (fig. 4)

Length: $44 \mathrm{~mm}$; Max. width: $13 \mathrm{~mm}$; Thickness: $3 \mathrm{~mm}$

9 It is a bone blade broken into two pieces. The exact nature of the bone could not be identified but it may be a hemi-mandible fragment (probable remnants of dental sockets on the lower side). The bone bears a head and neckline of an incomplete animal facing towards the left.

We think that this animal represents a reindeer. We can identify the ear, which is slightly stretched upwards and towards the rear. As the antlers are absent, due to the fact that the piece is broken, it is not possible to attribute a genus or species to the animal with certainty.

11 The eye is striking due to the formal technique adopted. It is drawn without a pupil, by a diamond extended by a lachrymal caruncle and is framed by two fine lines that evoke the fur of the orbital projection. Fur lines can be observed in front of the ear and along the cervical and dorsal contour.

The style of this representation conforms to realist middle and upper Magdalenian iconography.

The precision of the line and the depiction of anatomical details are exceptional.

Piece $\mathrm{n}^{\circ} 2$ (Inventory number PCR - PDA62) (fig. 5)

Length: $24 \mathrm{~mm}$; Max. width: $14 \mathrm{~mm}$; Thickness: $1 \mathrm{~mm}$

The second piece is a fragment of flat bone (probably a scapula), broken into two parts. The bone bears traces of burning which seem to be anterior to the engraving.

The represented figure is a red deer protome facing left. The engraving is cut off at the neckline by the break. The head is well proportioned. The eye, the nostrils and the mouth are absent. The ear is suggested and the antlers can be seen clearly. The layout, the way they are represented and the number of tines are consistent with those of real animals. It is possible to identify the basal tine, the top tine and perhaps the central tine. Some of the outlines are double lines and appear to represent both antlers in perspective. At the edge of the bone, we can see the rest of the stave (stave B).

The neckline is robust. A curved line underlines the back of the cheek. The fur on the neck is illustrated by a series of very fine interconnected lines.

The originality of this representation resides in its dimensions. The red deer measures $1.4 \mathrm{~cm}$ from the top of the tine to the base of the neckline and is less than $1 \mathrm{~cm}$ wide.

19 This is one of the smallest known representations in the corpus of Paleolithic portable art. It is a miniature which can be compared to certain upper Magdalenian portable objects of art from Bourrouilla Cave at Arancou (Pyrénées-Atlantiques) (Chauchat dir. 1999; Aurière et al. 2013). The contour line (less than $1 \mathrm{~mm}$ wide) was observed with a stereomicroscope and was etched with the same tool, in a continuous and single gesture, without going back over the line. The marks of the tool used for the wide flatbottomed line are perfectly preserved with a very clear "barcode" effect (Fritz 1999). 
This representation illustrates exceptional engraving skills, in both the dexterity of the gesture and the skilled use of the tool and technique. It nonetheless raises questions concerning practical engraving aspects. The macroscopic observation and more detailed microwear analysis will bring to light the exact engraving modalities of these lines and identify the type of tool used by the artist among the panoply of lithic tools known at the site (Fritz 1999).

Piece $n^{\circ} 3$ (Inventory number PCR - PDA50) (fig. 6)

Length: $21 \mathrm{~mm}$; Max. width: $8.5 \mathrm{~mm}$; Thickness: $2 \mathrm{~mm}$

The last object is a fragment of burnt bone decorated with two superposed sequences of small curved lines shaped like nested accents. It depicts a simple geometric pattern which is quite frequent in upper and final Magdalenian art.

Figure 4 - Engraved bone with a reindeer head(?) (PDA61). Photo and drawing E. Man-Estier.

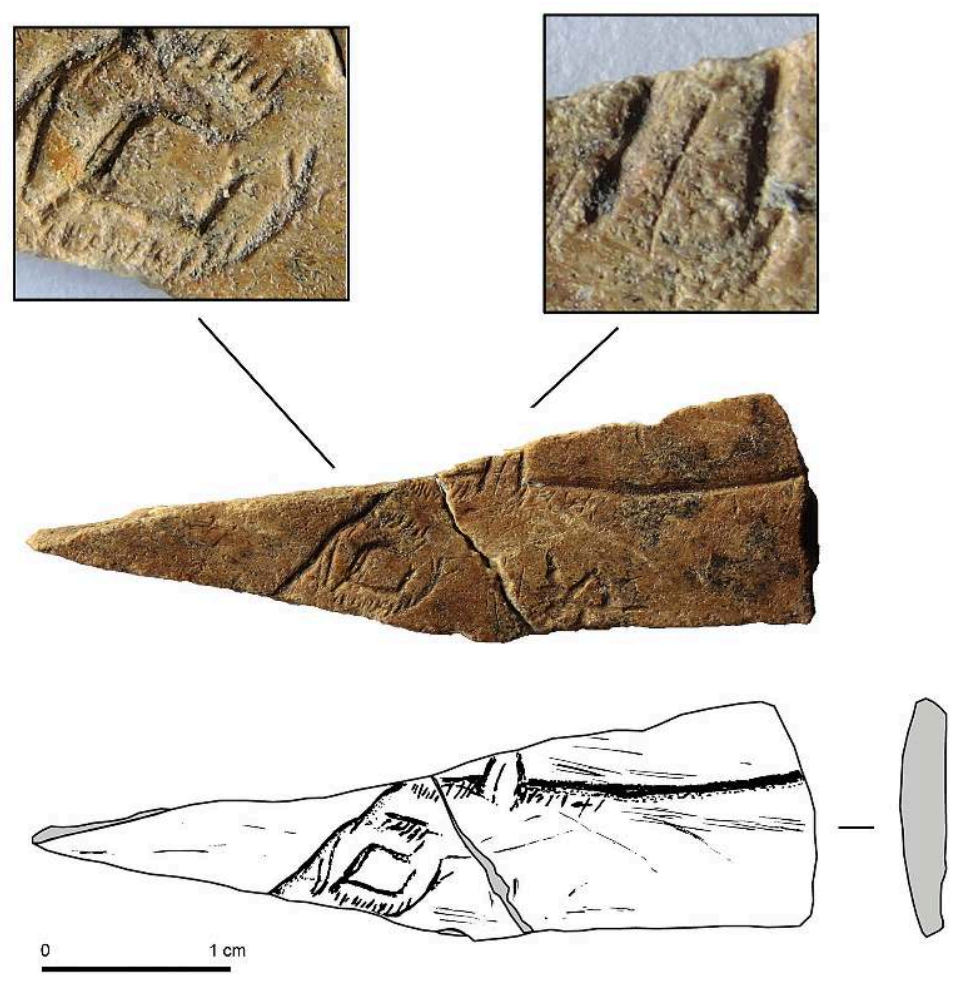

\section{Cultural and symbolic relations}

The site of Pont d'Ambon is located several hundred metres from the small cave of Rochereil (Grand-Brassac) and less than two kilometres from the cliffs of La Peyzie (Lisle), which contain several habitats identified by P.-E. Jude. These sites are all ascribed to the upper Magdalenian. The corpus of portable art from Rochereil is among the most abundant collections known for this period (Jude 1960; Paillet 2012; ManEstier and Paillet 2013). At La Peyzie, several works of art have been documented but are not issued from a well-defined stratigraphic context (Paillet in press). In many respects, the two Magdalenian figurative representations from Pont d'Ambron are comparable to them. They have similar stylistic characteristics and the fur is depicted in a similar way. These details are part of a wider graphic tradition known throughout 
the Perigordian upper Magdalenian. However, the red deer protome also recalls several exceptionally small pieces from contemporaneous sites in the Pyrenees (La Vache, Bourrouilla). These objects raise the question of middle and long distance relations between populations and the role of the sites of Pont-d'Ambon, Rochereil and La Peyzie in an extended cultural territory.

Figure 5 - Engraved bone with a deer protomé (PDA62). Picture and drawing P. Paillet.
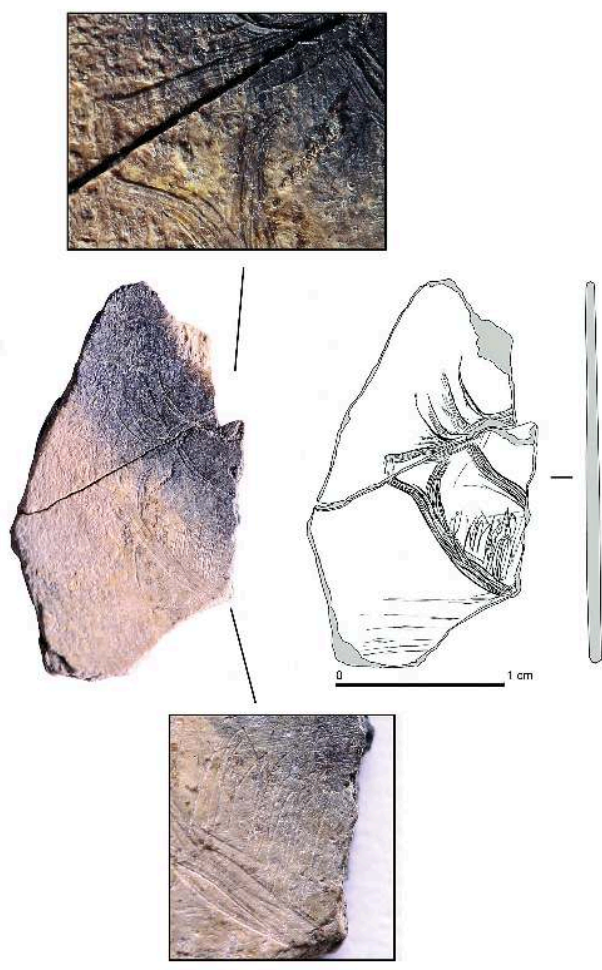

Figure 6 - Engraved bone with small curved lines (PDA50). Photo P. Paillet.

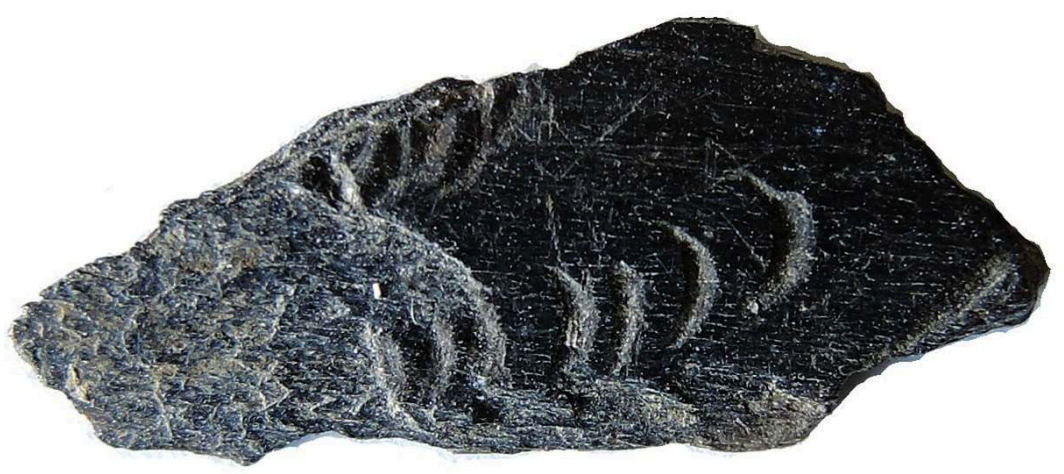

0 $1 \mathrm{~cm}$ 


\section{Provisional conclusions}

The two figurative representations identified on these small fragmented bones have clear formal and esthetic qualities, in different stylistic and expressive modes. The discovery of these rare decorated objects in the Magdalenian context of Pont d'Ambron is fundamental for the analysis of the site and the presumed links with the two neighbouring and allegedly contemporaneous sites of Rochereil (Grand- Brassac) and La Peyzie (Lisle). According to G. Célérier, the site of Pont d'Ambon does not present any decisive criteria indicating that this site was a meeting place due to the absence of portable art (Célérier 1992). The three objects presented here do not represent firm evidence of a contradictory viewpoint, given the general paucity of the Magdalenian levels from Pont d'Ambon, which were only excavated over one square metre, compared to those of Rochereil, which are characterized by abundant objects of art. But the presence of three engraved bones enables us to clarify the picture and to establish links between the three neighbouring sites, links which were widespread during the Epipaleolithic sequence. Furthermore, these partial data attest to the probable abundance of the Magdalenian occupations from Pont d'Ambon, which are unfortunately inaccessible below the level of the water table and the present day Dronne under normal flow rate conditions. Lastly, these discoveries also prove that reviewing collections, even recent series, always entails surprises.

\section{BIBLIOGRAPHY}

AURIÈRE L., CHAUVIÈRE F.-X., PLASSARD F., FRITZ C. et DACHARY M. 2013 - Art mobilier inédit du gisement de Bourouilla à Arancou : données techno-stylistiques et chrono-culturelles, Paleo, 24, p. XXX-XXX.

CÉLÉRIER G. 1991 - Pont d'Ambon (Bourdeilles), Gallia Informations, p. 11-12.

CÉLÉRIER G. 1992 - Á propos de trois habitats magdaléniens de la vallée de la Dronne et la notion de site de rassemblement, Paleo, 4, p. 155-159.

CÉLÉRIER G. 1996 - L'abri sous roche de Pont d'Ambon à Bourdeilles (Dordogne) : l'industrie osseuse et la parure, Gallia préhistoire, t. 38, p. 69-110.

CÉLÉRIER G. 1998 - L'abri sous roche de Pont d'Ambon à Bourdeilles (Dordogne, France). Perpectives synthétiques, Paleo, 10, p. 233-264.

Chauchat C. (dir.), Fontugne M., hatTe C., DAchary M., BONNISSENT D., ChAuVIÈre F.-X., ROUSSOT A., FRITZ C., FOSSE P., EASTHAM A., MARTIN H., LE GALL O., GAMBIER D. 1999 - L'habitat Magdalénien de la grotte Bourrouilla à Arancou (Pyrénées Atlantiques), Gallia Préhistoire, t. 41, p. 1-151

FRITZ C. 1999 - La gravure dans l'art mobilier magdalénien. Du geste à la représentation. Documents d'Archéologie Française (DAF) nº 75, Éditions de la Maison des Sciences de l'Homme, Paris, 217 p. JUDE P.-E. 1960 - La Grotte de Rochereil. Station magdalénienne et azilienne. Archives de l'I.P.H., Mémoire $\mathrm{n}^{\circ} 30$, Paris, $75 \mathrm{p}$. 
MAN-ESTIER E. et PAILLET P. 2013 - Rochereil et l'art magdalénien de la fin du Tardiglaciaire dans le Nord du Périgord (Dordogne, France) In : GROENEN M (dir.), Expressions esthétiques et comportements techniques au Paléolithique, Actes des sessions thématiques 36 et 37 du 16 ème Congrès mondial de l'UISPP (Florianopolis, Brésil, 4-10 septembre 2011), BAR International series, vol. 3, Archaeopress, Oxford, p. 7-36.

PAILLET P. 2012 - Men and cultures at the end of the late Ice age in the north of Perigord: continuities and ruptures. Pré-Actes (Session papers) International Conference on Rock Art, 06-13 December, 2012, Understanding Rock Art in Context, Indira Gandhi National Centre For The Arts, New Delhi, Inde, p. 54-65.

PAILLET P. sous presse - Deux bâtons percés inédits de la Peyzie (Lisle, Dordogne), Paleo, numéro spécial.

PAILLET P. et MAN-ESTIER E. soumis et accepté - De nouvelles découvertes d'art mobilier laborien dans le Nord du Périgord, Actes des séances de la S.P.F., Les sociétés de l'Alleröd et du Dryas récent entre Atlantique et Méditerranée, Bordeaux, mai 2012.

\section{ABSTRACTS}

A systematic and methodical review of fauna collections from the site of Pont d'Ambon (excavation G. Célérier), conducted as part of a Collective Research Project centered on the end of the Late Ice Age in northern Perigord, has permitted the discovery of three objects of portable art in an upper Magdalenian context, perfectly located in the site on an archeostratigraphic perspective (layer 5, square J8). These are the first portable art pieces found in the Magdalenian levels of Pont d'Ambon, excavated only on $1 \mathrm{~m}$. As a first presentation, the authors propose a brief reading of these pieces and reveal their originality and technical as well as stylistic characteristics.

Une révision systématique et méthodique des collections fauniques provenant du site de Pont d'Ambon (fouilles G. Célérier), réalisée dans le cadre du Projet Collectif de Recherche «Peuplements et cultures à la fin du Tardiglaciaire dans le Nord du Périgord", dirigé par P. Paillet, a permis la découverte de trois objets d'art mobilier en contexte magdalénien supérieur, localisés dans le site du point de vue archéostratigraphique (couche 5, carré J8). Il s'agit des premières œuvres d'art découvertes dans les niveaux magdaléniens de Pont d'Ambon, fouillés seulement sur $1 \mathrm{~m}$. Sous forme d'une prise de date, les auteurs proposent une première et brève lecture de ces pièces et en révèlent l'originalité et les spécificités techniques et stylistiques.

\section{INDEX}

Keywords: portable art, Magdalenian, Pont d'Ambon, bone supports, figurative art

Mots-clés: art mobilier, Magdalénien, pont d'Ambon, supports osseux, art figuratif

\section{AUTHORS}

\section{PATRICK PAILLET}

Muséum national d'Histoire naturelle, département de Préhistoire - UMR 7194 Histoire naturelle de l'Homme préhistorique - paillet@mnhn.fr 


\section{ELENA MAN-ESTIER}

Centre national de Préhistoire, Ministère de la Culture et de la Communication et UMR 5199 PACEA - elena.man-estier@culture.gouv.fr

\section{PEGGY BONNET-JACQUEMENT}

Musée national de Préhistoire, Ministère de la Culture et de la Communication et UMR5199

PACEA - peggy.jacquement@culture.gouv.fr 